\title{
ADAPTATION OF WHITE CLOVER TO MOISTURE STRESS
}

D.R. WOODFIELD and J.R. CARADUS

Grasslands Division, DSIR, Private Bag, Palmerston North

Abstract

In a series of four experiments, the w-seeding ability and shoot and root characteristics of dryland white clover populations (Trifolium repens L.), and the effect of selection for root characteristics within white clover were examined. There was little evidence that dryland populations were better at re-seeding than Huia, but dryland populations were more taprooted than populations collected from moister environments. Root morphologies of dryland populations were similar to that of Huia but were smaller leaved, although not as small leaved as Tahora. Evidence that selection for more taprooted, smaller-leaved types of white clover would be successful is also presented.

Keywords: root type, drought, re-seeding, plant breeding, survival.

\section{INTRODUCTION}

Increased survival and production of white clover in drought-prone areas may be achieved by breeding for (a) drought avoidance, through re-seeding prior to onset of moisture stress (O'Brien 1970), (b) improved moisture conservation through reduced leaf size, stomatal closure and high cuticular resistance (Parsons 1982), and (c) improved moisture uptake, through a more extensive, deeper or denser root system, and increased root to shoot ratio (Smith \& Morrison 1983, Stevenson \& Laidlaw 1985).

'Grasslands Huia', which has been used during the past 40 years to oversow dry hill country pastures in NZ, persists poorly in dry hill country (Charlton 1984), having been bred specifically for use in high fertility lowland.

Previous white clover root studies (Caradus 1977, 1981) have shown a strong correlation between root and shoot type, such that predominantly taprooted genotypes are larger leaved than fibrous rooted genotypes. A preliminary study investigating the effect of selection for smaller leaved, more taprooted types is also reported.

\section{MATERIALS AND METHODS}

\section{Experiment 1: Vegetative persistence and reseeding in North Canterbury}

In winter 1984, 106 lines of white clover including 61 lines from a NZ dry hill country ecotype collection, 5 lines of Whatawhata early flowering types, 24 lines of New Zealand $x$ Mediterranean crosses and other lines of diverse origin were established at a dry hill country farm (Carvossa) near Waikari, North Canterbury. Each line was represented by 60 genotypes, planted in 6 replicates as 10 plant rows.

The site was on a Tipapa hill soil, at $540 \mathrm{~m}$ a.s.l., with a 15 " slope and $550 \mathrm{~mm}$ annual rainfall. The area was regularly grazed after establishment, but closed during summer 1985/86 to allow re-seeding. In autumn 1986 the number of vegetatively surviving plants and the number of seedlings established around each planted row were counted.

\section{Root type experiments}

Plants for Experiments 2-4 were grown in Palmerston North in field tiles $(9 \mathrm{~cm}$ diameter $\times 37 \mathrm{~cm}$ deep) containing a $\mathbf{B}$ horizon Egmont loam to which $30 \%$ potassic superphosphate had been added at a rate of $1 \mathrm{~g} \mathrm{P} / \mathrm{kg}$ soil. Genotypes were propagated from stolon tips and pre-rooted in potting mix before transplanting into the tiles. Measurements were made in all experiments of leaflet width as a measure 
of shoot type, largest taproot diameter, number of taproots (basal diameter $>1 \mathrm{~mm}$ ), dry weight of taproots and fibrous roots, and shoot dry weight.

\section{Experiment 2: The evaluation of 30 white clover populations}

A total of 600 genotypes (20 genotypes of 30 populations $=$ Table 3 ) were evaluated. Each genotype was replicated twice. Plants were grown for 14 weeks in autumn-winter 1985.

Experiment 3: The evaluation of drought-surviving genotypes

125 white clover genotypes that had survived vegetatively through a very dry summer at Carvossa, North Canterbury were evaluated, along with six genotypes each of Huia, Tahora, Kopu, and Kent wild white. Each genotype was replicated twice. Plants were grown for 10 weeks in summer 1985.

\section{Experiment 4: The evaluation of selections for root and shoot type}

The root types of 220 genotypes from 45 populations of white clover were measured. Plants had been grown as spaced plants, at Palmerston North for 2 years prior to measurement. Plants were excavated to a depth of $10 \mathrm{~cm}$, soil was washed from roots, and measurements made. Plants which differed significantly for leaf size, number of taproots and percentage fibrous root were selected and crossed to produce eight selections (Table 1). Forty genotypes from each selection were evaluated for root type. Each genotype was replicated twice. Plants were grown for 9 weeks in summer 1985.

Table 1: Description of selections $1-8$ used in experiment 4.

\begin{tabular}{lccccc}
\hline Leaf size & \multicolumn{2}{c}{ No. of taproots } & \multicolumn{2}{c}{$\%$ Fibrous roots } \\
& High & LOW & High & LOW \\
\hline Large & 1 & 2 & 5 & 6 \\
Small & 3 & 4 & 7 & 8 \\
\hline
\end{tabular}

Table 2: The vegetative survival of planted material, the number of seedlings established per row and the area of population collection.

\begin{tabular}{lccc}
\hline Collection area & $\begin{array}{c}\text { No. of } \\
\text { populations }\end{array}$ & $\begin{array}{c}\text { Vegetative } \\
\text { survival }(\%)\end{array}$ & $\begin{array}{c}\text { Mean number of } \\
\text { seedlings/row }\end{array}$ \\
\cline { 2 - 4 } Whatawhata & 5 & 2.4 & 3.0 \\
Taupo & 4 & 1.7 & 1.6 \\
Poverty Bay & 3 & 2.2 & 1.7 \\
Hawke's Bay & 9 & 2.0 & 2.1 \\
Southern Hawke's Bay & 9 & 3.8 & 2.1 \\
Wairarapa & 10 & 3.7 & 1.6 \\
Marlborough & 8 & 3.3 & 1.6 \\
North Canterbury & 6 & 6.7 & 2.3 \\
Canterbury & 5 & 7.3 & 2.4 \\
Central Otago & 6 & 4.2 & 1.2 \\
N2 X Mediterranean & 24 & 1.6 & 1.5 \\
Other NZ lines & 12 & 2.0 & 1.6 \\
cv. Huia & & 1.7 & 3.8 \\
cv. Pitau & 1 & 2.0 & 2.3 \\
cv. Kopu & 1 & 0.0 & 2.0 \\
Cv. Tahora & 1 & 0.0 & 1.0 \\
Cv. Kent Wild White & 1 & 0.0 & 0.0 \\
LSD... & & 2.1 & 0.7 \\
\hline
\end{tabular}

\section{RESULTS}

\section{Experiment 1}

Re-seeding. Lines selected for early flowering and high seed yields at Whatawhata and populations collected from Canterbury and North Canterbury had greater seedling establishment than those derived from crosses between New 
Zealand and Mediterranean material (Table 2). The high reseeding of Huia and low reseeding of Tahora are also of interest.

Vegetative persistence. Persistence was very low for all lines following the summer drought of $1984 / 85$, with only $3 \%$ of all plants surviving. However, two populations originally collected from North Canterbury $(28 \%$ and $20 \%)$ and 10 populations from Canterbury, Marlborough, Wairarapa and Southern Hawke's Bay had over $10 \%$ survival. Overall, collections from North Canterbury and Canterbury showed superior vegetative persistence (Table 2). No plants of Kopu or Tahora survived.

\section{Root type - Experiments $2-4$}

Comparison of populations. Populations collected from dryland sites either had a similar or significantly smaller leaf size than Huia, but only one population (number 28 from Wither Hills) had a significantly smaller leaf size than Tahora (Table 3). Only two dryland populations (numbers 27 and 28, both from Wither Hills) had significantly smaller taproot diameters and fewer taproots than Huia, the remainder were not significantly different (Table 3 ).

Table 3: Description of populations and mean leaflet width, taproot diameter. taproot number and total fresh weight (FW) after 14 weeks growth in field tiles (Experiment 2).

\begin{tabular}{|c|c|c|c|c|c|c|}
\hline \multirow{2}{*}{$\begin{array}{l}\text { NO. } \\
1\end{array}$} & \multicolumn{2}{|c|}{$\begin{array}{l}\text { C-cultivar } \\
\text { S-selection } \\
\text { E-ecotvpe }\end{array}$} & \multirow{2}{*}{$\begin{array}{c}\begin{array}{c}\text { Leaflet } \\
\text { width } \quad(\mathrm{mm})\end{array} \\
11.9\end{array}$} & \multirow{2}{*}{$\begin{array}{c}\begin{array}{c}\text { Taproot } \\
\text { diameter } \\
(\mathbf{m m})\end{array} \\
1.96\end{array}$} & \multirow{2}{*}{$\begin{array}{c}\begin{array}{c}\text { Number of } \\
\text { taproots } \\
\text { per plant }\end{array} \\
6.9\end{array}$} & \multirow{2}{*}{$\begin{array}{c}\begin{array}{c}\text { Total } \\
\text { F.W. (g) } \\
\text { per plant }\end{array} \\
14.9\end{array}$} \\
\hline & c & Huia & & & & \\
\hline 2 & c & Tahora & 17.3 & 1.93 & 6.1 & 16.2 \\
\hline 3 & c & Kopu & 9.9 & 1.83 & 6.3 & 13.6 \\
\hline 4 & $\mathrm{~s}$ & G.23 & 17.1 & 2.17 & 6.2 & 15.6 \\
\hline 5 & $\mathrm{c}$ & Dusi, South Africa & 17.7 & 2.22 & 6.4 & 15.7 \\
\hline 6 & $\mathbf{s}$ & Root knot nematode tolerant & 15.2 & 2.15 & 0.2 & 20.6 \\
\hline 7 & $\mathbf{s}$ & Southland selection & 8.6 & 1.62 & 6.1 & 10.4 \\
\hline 8 & $\mathrm{E}$ & Sheep farms, Northland & 11.5 & 1.69 & 5.7 & 14.4 \\
\hline $\begin{array}{r}9 \\
10\end{array}$ & $\begin{array}{l}E \\
E\end{array}$ & $\begin{array}{l}\text { Dairy farms, Northland } \\
\text { Whatawhata HCRS } \neq\end{array}$ & $\begin{array}{l}11.6 \\
10.4\end{array}$ & $\begin{array}{l}1.65 \\
1.75\end{array}$ & $\begin{array}{l}4.0 \\
5.3\end{array}$ & $\begin{array}{r}7.5 \\
14.6\end{array}$ \\
\hline 11 & $\mathrm{~s}$ & Whatawhata early flowering & 12.1 & 2.01 & 4.6 & 13.0 \\
\hline 12 & $\mathrm{E}$ & Ballantrae HCRS $\neq$ & 6.6 & 1.42 & 3.6 & 5.6 \\
\hline 13 & $E$ & Devon, England & a. 3 & 1.58 & 4.0 & 6.2 \\
\hline 14 & $\mathrm{E}$ & Cheviot Downs, Canterbury & 11.2 & 1.94 & 5.9 & 12.9 \\
\hline 15 & s & High yields at low-P & 7.7 & 1.39 & 3.0 & 6.1 \\
\hline 16 & S & Low yields at low-P & 0.7 & 1.42 & 2.6 & 5.2 \\
\hline 17 & E§ & Pukewhinau, Sth, Hawkes Say & 10.3 & 1.74 & 6.4 & 14.0 \\
\hline 18 & E\$ & Horoeka, Sth. Hawkes Bay & 10.7 & 1.73 & 6.2 & 13.3 \\
\hline 19 & ES & Akitio, Sth. Hawkes Say & 11.6 & 2.00 & 6.5 & 15.5 \\
\hline 20 & E\$ & Ruakawa, Hawkes Bay & 9.6 & 1.91 & 5.3 & 11.9 \\
\hline 21 & $E \S$ & Castlepoint. Wairarapa & 11.6 & 2.08 & 7.3 & 19.5 \\
\hline 22 & ES & Summerhill, Wairarapa & 11.6 & 1.99 & 5.3 & 11.3 \\
\hline 23 & ES & Weber, Sth. Hawkes Bay & 11.0 & 2.08 & 6.4 & 15.3 \\
\hline 24 & ES & Hawarden, Nth. Canterbury & 7.5 & 1.02 & 5.4 & 6.3 \\
\hline 25 & E\$ & Cheviot 1, Nth. Canterbury & 6.4 & 1.64 & 4.6 & 8.0 \\
\hline 26 & E\$ & Cheviot 2. Nth. Canterbury & 7.4 & 1.74 & 5.9 & 6.1 \\
\hline 27 & ES & Wither Hills 1, Marlborough & 6.2 & 1.50 & 4.4 & 7.3 \\
\hline 26 & $E \S$ & Wither Hills 2. Marlborough & 7.2 & 1.55 & 2.6 & 5.9 \\
\hline 29 & $E \S$ & Tara Hills, Central Otago & 9.4 & 1.60 & 6.1 & 11.2 \\
\hline \multirow[t]{3}{*}{30} & $E \S$ & Mt. Stoker, Central Otago & 9.7 & 1.93 & 7.5 & 11.2 \\
\hline & & $\mathrm{P}$ & $* * *$ & $* *$ & at* & $\ldots$ \\
\hline & & $\begin{array}{l}\text { \&MSD } \\
\text { or } M S R_{0.03}\end{array}$ & 1.6 & 0.40 & 2.5 & $\mathrm{xl} .9$ \\
\hline
\end{tabular}

$\S$ Dryland collection $\ddagger$ Hill country research station

$\$ M S D=$ minimum signitant difference

$M S R=$ minimum significant ratio (Sokal and Rolfe 1961) 
Four dryland populations (Summerhill, Hawarden, Cheviot 2 and Mt. Stoker) were characterised by having a high proportion of taproot as well as a high proportion of root compared with populations collected from wetter environments (Figure 1). Dusi, a South African cultivar bred specifically for drought tolerance, had a high proportion of root but a low proportion of taproot.

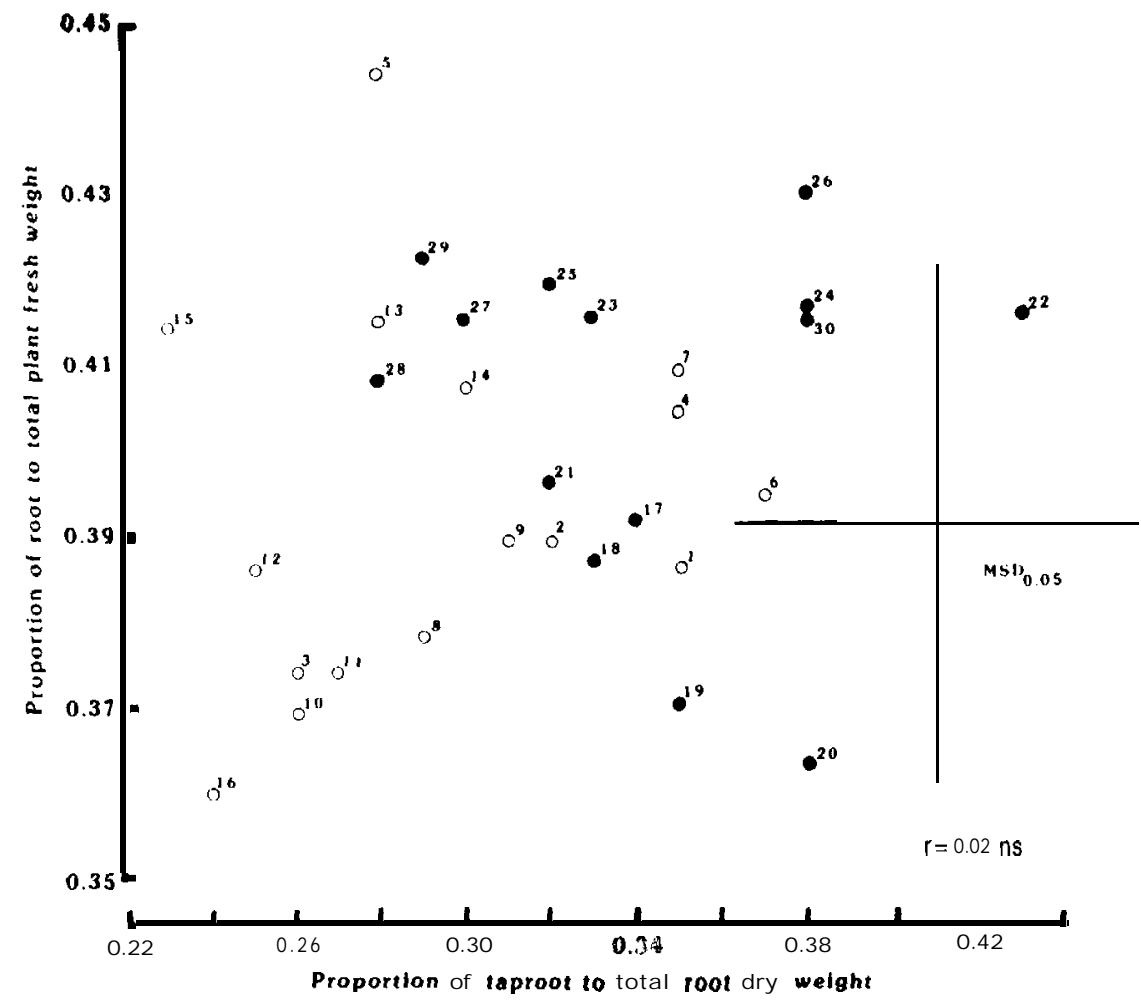

Figure 1: The relationship between proportion of taproot to total root dry weight and proportion of root to total plant fresh weight for 30 white clover populations. Populations collected from dryland sites are denoted by $\bullet$; other populations by 0 . Population description are given in Table 3.

In experiment 1 , genotypes that survived vegetatively at Carvossa were smaller leaved, but had a similar root morphology compared with Huia (Table 4). These genotypes were, however, more taprooted, and had a higher proportion of root than Tahora.

Effect of selection for root and shoot type. The selection for plants with different root and shoot type was a partial success (Figure 2): lines 7 and 8 were both small leaved and line 8 more taprooted than line 7; lines 1 and 2 were both large leaved and line 1 more taprooted than line 2; and line 5 was large leaved and had few taproots. However, the other three selections were less satisfactory; line 6 was too small leaved and was not taprooted enough; line 3 was taprooted but its leaves were too large and line 4 was small leaved but more taprooted than expected. 
Table 4: Leaflet width and root morphology of cultivars Huia, Tahora, Kopu and Kent Wild White compared with genotypes which survived a dry summer at Carvossa. Standard errors are given.

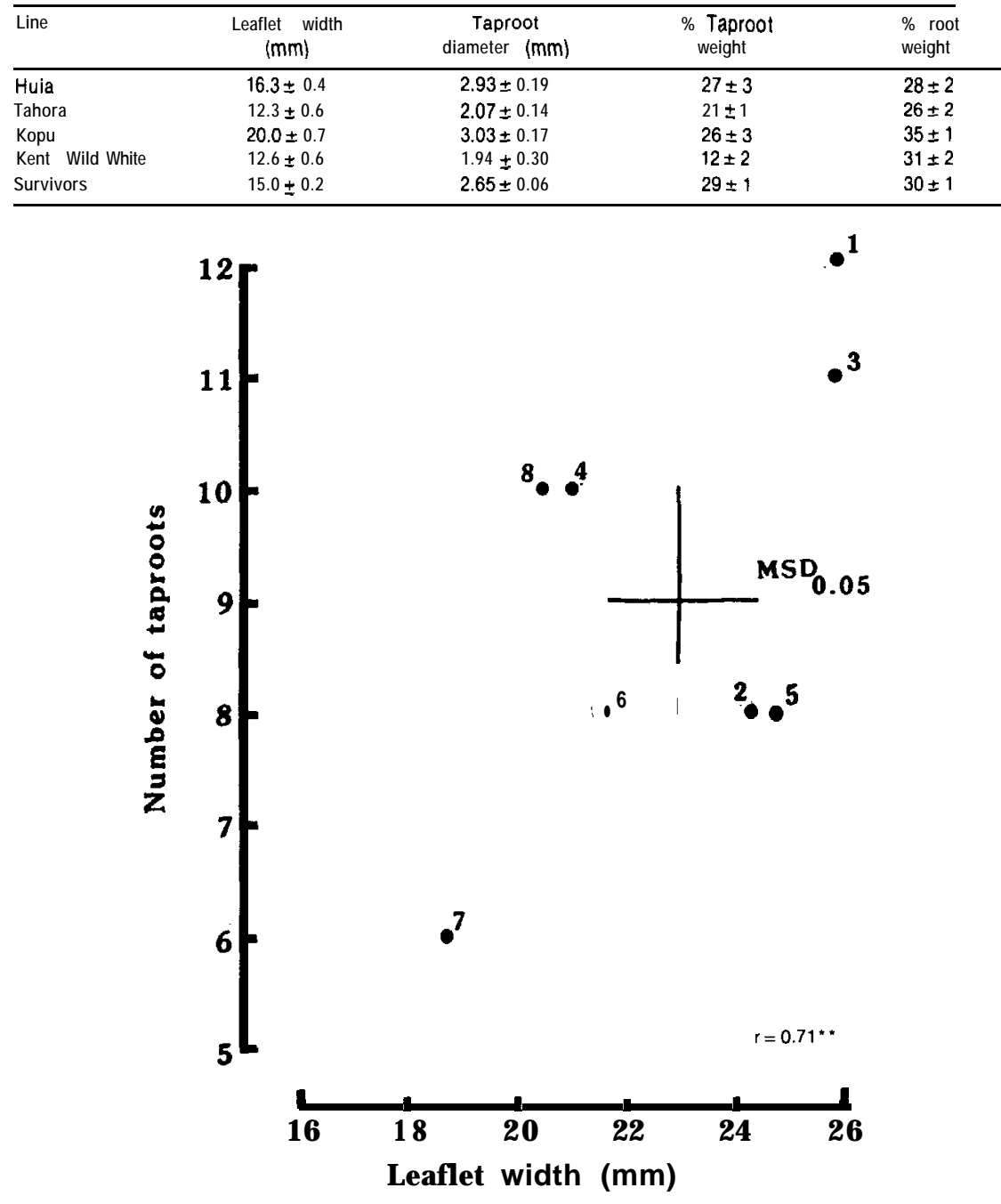

Figure 2: The leaf size and number of taproots of eight lines selected for root and shoot morphology (Table 1).

\section{DISCUSSION}

Reseeding and vegetative persistence

In previous studies there is evidence that dryland populations of white clover may be better at reseeding than Huia, Pitau, Kopu or Tahora (MacFarlane \& Sheath 1984). However, in the present study, Huia had the highest reseeding ability, although the reseeding abilities of collections from Whatawhata and several other dryland regions were also high (Table 2).

The significantly better vegetative survival of populations originating from North 
Canterbury and Canterbury (Table 2) indicates that selecting for regional cultivars using adapted ecotypes is likely to give an improvement in drought tolerance. Populations from Canterbury and North Canterbury also showed reasonable seedling re-establishment, indicating that unless reseeding ability can be shown to be the main mechanism of persistence it will not be necessary to consider reseeding separately in breeding a cultivar for this environment.

Chapman (1966) showed that seedling regeneration plays a minor role in white clover persistence in moist hill country compared to vegetative persistence through high stolon densities and high rates of stolon initiation. If these results apply to dry hill country also, then breeding for better reseeding ability will not be worthwhile.

Neither Tahora, bred for moist hill country (Williams et al. 1982) nor Kopu, bred for intensive lowland farming (van den Bosch et al. 1986) survived the moisture stress at Carvossa and showed only moderate reseeding ability. Neither cultivar could be recommended as a replacement for Huia in North Canterbury dry hill country.

Root type

Dry hill country populations appear to be more taprooted than populations (2, 7, $12,15,16)$ collected from moist hill country environments (Table 3 ). This is partly due to the larger leaf size of dry hill country populations but also to a larger taproot diameter and higher number of taproots at this leaf size. The correlation between leaf size and taproot diameter, and leaf size and taproot number is strong (Caradus 1977, 1981; Caradus \& Woodfield 1986). However the dryland populations from Hawarden (24) and Cheviot 2 (26) had a larger taproot diameter and more taproots, and the population from Mt Stoker (30) more taproots than expected from their leaf size.

The lack of a linear relationship (Figure 1) between the proportion of root weight to total plant weight, and the proportion of taproot to total plant weight suggests that these characters could be selected independently to improve root type in white clover for dryland environments. The use of the root:shoot and taproot:total root dry weight ratios as selection criteriadoes have limitations, since plants with high or low shoot yields (and root yields) can have high root:shoot ratios and a high proportion of taproot. When using these ratios to select plants, it is important to use shoot or total plant yield as a covariate. Of the populations which had both a high proportion of root and taproot, Summerhill (22) and Mt Stoker (30) have reasonable shoot yields (Figure 2, Table 3).

In general, dryland populations (Table 3) and the survivors after drought (Table 4) had similar root morphologies to that of Huia, but were smaller leaved. There is evidence that smaller leaved white clovers are more persistent under sheep grazing (Davies \& Levy 1931; Williams \& Caradus 1979). Dryland populations appear to have adapted to moisture stress by retaining the root structure of a Huia type while having a smaller leaf size and lower shoot yield. This is not surprising as many of these dryland populations were collected from sites where only Huia or Ni! Certified Mother had been sown.

Ennos (1985) also found that there was significant genetic variation in root growth within a single collected population of white clover, and showed that the heritability of root length is high $(0.42-0.84)$. The heritability will vary between populations depending on the homogeneity or heterogeneity of the population, but heritabilities of this order indicate that selection for root type independent of leaf size will be successful, as in Experiment 3 (Figure 2).

These results will be used by breeders to select small and medium leaved lines with larger and more frequent taproots for further testing in dryland environments.

\section{Acknowledgements}

A. Sackfield, J. Moran and the plant breeding technicians for technical assistance, J.R. Sedcole for assistance with statistical analyses, and P. Lamb for the use of the Carvossa trial site. 


\section{References}

Caradus J.R. 1977. Structural variation of white clover root systems NZ Journal of Agricultural Research 20 : 213.219.

Caradus J.R. 1981. Root morphology of some white clovers from NZ hill country. NZ Journal of Agricultural Research 24: 349-351.

Caradus J.R., Woodfield D.R. 1986. Root type evaluation of white clover genotypes and populations. Proceedings of Plant Breeding Symposium Lincoln, N.Z. 1986. (In press).

Chapman D.F. 1986. Natural re-seeding and Trifolium repens demography in grazed hill pastures. III. Seedling appearance and survival. Journal of Applied Ecology (In press).

Chapman D.F., Sheath G.W., MacFariane M.J., Aumball P.J.. Cooper B.M., Crouchley G., Hoglund J.H. Widdup K.G. 1986. Performance of subterranean and white clover varieties in dry hill country. Proceedings NZ Grassland Association 47: 53-62.

Charlton J.F.L. 1984. Persistence of Grasslands Huia white clover (Trifolium repens L.) in hill country pastures. Proceedings NZ Grass/and Association 45: 131.139.

Davies W., Levy E.B. 1931. Strain investigations of grasses and clovers. 4. White clover (Trifolium repens L.). NZ Journal of Agriculture 42: 75-89.

Ennos R.A. 1965. The significance of genetic variation for root growth within a natural population of white clover (Trifolium repens L.). Journal of Ecology 73: 615.624.

MacFarlane M.J., Sheath G.W. 1964. Clover - What types for dry hill country. Proceedings NZ Grassland Association 45: 140-150

O'Brien A.D. 1970. White clover (Tritolium repens L.) in a subtropical environment on the east coast of Australia Proceedings XI International Grassland Congress: 165168.

Parsons L.R. 1982. Plant responses to water stress. pp 175.192. In Christiansen M.N.; Lewis C.F. (Eds). Breeding Plants for less Favourable Environments. Wiley and Sons, New York.

Smith A., Morrison A.R.J. 1983. A deep rooted white clover for South African conditions. Proceedings Grassland Society of South Africa 18: 50-52.

Sokal R.R., Rolfe F.J. 1981. Biometry. 2nd Edition. W.H. Freeman and Co, San Francisco.

Stevenson C.A., Laidlaw A.S. 1985. The effect of moisture stress on stolon and adventitious root development in white clover (Trifollum repens L.). Plant and Soil 85: 249-257.

van den Bosch J., Lancashire J.A., Cooper B.M., Lyons 1.0.. Williams W.M. 1986. G18 white clover - a new cultivar for intensive lowlands. Proceedings NZ Grassland Association 47: 173-177.

Williams W.M., Caradus J.R. 1979. performance of while clover lines on New Zealand hill country. Proceedings NZ Grassland Association 40: 162.169.

Williams W.M., Lamberl M.G., Caradus J.R. 1982. Performance of a hill country while clover selection. Proceedings NZ Grassland Association 43: 166.195. 